\title{
Seed Size and Its Influence on Growth-Related Agronomic Characters of Wheat Plants
}

\author{
Gustavo Henrique Demari ${ }^{1}$, Ivan Ricardo Carvalho ${ }^{1}$, Vinícius Jardel Szareski ${ }^{1}$, Simone Morgan Dellagostin ${ }^{1}$, \\ João Roberto Pimentel ${ }^{1}$, Cristian Troyjack ${ }^{1}$, Tiago Corazza da Rosa ${ }^{1}$, Velci Queiróz de Souza ${ }^{2}$, \\ Paulo Dejalma Zimmer ${ }^{1}$, Francisco Amaral Villela ${ }^{1}$, Tiago Pedó ${ }^{1} \&$ Tiago Aumonde Zanatta ${ }^{1}$ \\ ${ }^{1}$ Federal University of Pelotas, Pelotas, Rio Grande do Sul, Brazil \\ ${ }^{2}$ Federal University of Pampa, Dom Pedrito, Rio Grande do Sul, Brazil \\ Correspondence: Ivan Ricardo Carvalho, Federal University of Pelotas, Pelotas, Rio Grande do Sul, Brazil. \\ E-mail: carvalho.irc@gmail.com
}

Received: January 8, 2019

doi:10.5539/jas.v11n12p29
Accepted: March 11, 2019 Online Published: July 31, 2019

URL: https://doi.org/10.5539/jas.v11n12p29

\begin{abstract}
The objective of this work was to evaluate the influence of seed size on agronomic traits related to the growth of wheat plants. The seeds used in this experiment were collected in growing fields from the North of Rio Grande do Sul, Brazil. The experimental design was randomized block design, with three wheat cultivars (Quartzo, Ametista and TBIO Sinuelo) $\times$ six seed lots (A; B; C; D; E; F) $\times$ five sieve diameters: I: (original sample without standardization, being that used by farmers $(\mathrm{OS})$ ), II: (seeds $>3.00 \mathrm{~mm}$ ), III: (seeds from 2.5 to $2.99 \mathrm{~mm}$ ), IV: (seeds from 2.0 to $2.49 \mathrm{~mm}$ ) and V: (seeds $<2.0 \mathrm{~mm}$ ), and the treatments were arranged in three replicates. The number of tillers per plant, height and spike insertion height are determined by intrinsic characteristics of the cultivar used, but extensive variations are attributed by lot fragmentation and seed size. The morphological and growth attributes of wheat are affected by considerable effects of seed size, and the decrease in these dimensions results in lower plants and reduced growth. The use of sieves for wheat seeds standardization allows the identification and selection of specific cultivars, lots and seed dimensions that may be essential for wheat crop performance.
\end{abstract}

Keywords: Triticum aestivum L., production of seeds, managements of plants

\section{Introduction}

Wheat (Triticum aestivum L.) belongs to the Poaceae family, with annual cycle, being used for human and animal feeding. Worldwide production in 2017 was 740 million tons of grains (FAO, 2017), of which, Brazilian production accounts for 5.7 million tons, and growing area of approximately 1.9 million hectares. Of this amount, the Southern Region of Brazil produced 4.6 million tons of grains, being Rio Grande do Sul state one of the largest producers, with 1.6 million tons (CONAB, 2018).

Currently, the average wheat yield in Brazil is $2431 \mathrm{~kg}$ per hectare of grains (CONAB, 2018), which is considered low, and can be improved by seeds standardization. It allows to remove seeds with undesirable physiological quality, to improve sowing management, to enhance the performance of plants at field, and thereby to increase yield, since the physiological quality of seeds is determined by chemical, sanitary, physiological and physical attributes (Martin et al., 2016). These attributes influence on germination, vigor, initial seedling development and phytomass accumulation (Brzezinski et al., 2014).

Considering the fact that there is no standardization of wheat seeds, one lot might present seeds of varying length, width and thickness. The seeds are separated by specific weight, resulting in lots composed by seeds with different sizes, which can present different physiological quality and performance (Pádua et al., 2010), as reported by studies with soybean (Pádua et al., 2010, Barbosa et al., 2010), and maize (Vazquez et al., 2012). Considering wheat crop, few studies consider this influence on agronomic traits related to growth, yield components, lodging and mechanized harvest (Carvalho et al., 2016). In this context, the objective of this work was to evaluate the influence of seed size on agronomic traits related to the growth of wheat plants. 


\section{Material and Methods}

The seeds used in this experiment were collected in growing fields from the North of Rio Grande do Sul, Brazil (Table 1), and the choice of cultivars was due to their adaptability to the culture environment. In the laboratory of the Seed Science and Technology Graduate Program of the Federal University of Pelotas, the seeds were standardized through a set of oblong hole sieves, separating the width $>3.00 \mathrm{~mm}$ (seed retained in the $3.0 \mathrm{~mm}$ sieve), 2.5 to $2.99 \mathrm{~mm}$ (seed retained in the $2.5 \mathrm{~mm}$ sieve which passed through the $3.0 \mathrm{~mm}$ sieve), 2.0 to 2.49 $\mathrm{mm}$ (seed which passed through the $2.5 \mathrm{~mm}$ sieve and retained in the $2.0 \mathrm{~mm}$ sieve), and $<2.0 \mathrm{~mm}$ (seeds that passed through the $2.0 \mathrm{~mm}$ sieve).

Posteriorly, the experiment was sown at field in the municipality of Tenente Portela-RS, in the agricultural year of 2016, under latitude $27^{\circ} 23^{\prime} 31.04^{\prime \prime} \mathrm{S}$, longitude $53^{\circ} 46^{\prime} 50.71^{\prime \prime} \mathrm{W}$, and altitude of 420 meters. The climate is characterized as subtropical humid type Cfa, according to Köppen, with annual precipitation of $2085 \mathrm{~mm}$ (Sotério et al., 2005). The soil is classified as typical alumino-ferric red latossolo (Streck, 2008).

The experimental design was randomized block design, with three wheat cultivars (Quartzo, Ametista e TBIO Sinuelo) $\times$ six seed lots $(A ; B ; C ; D ; E ; F) \times$ five sieve diameters: I: (original sample without standardization, being that used by farmers (OS)), II: (seeds $>3.00 \mathrm{~mm}$ ), III: (seeds from 2.5 to $2.99 \mathrm{~mm}$ ), IV: (seeds from 2.0 to $2.49 \mathrm{~mm}$ ) and V: (seeds $<2.0 \mathrm{~mm}$ ), and the treatments were arranged in three replicates. The experimental units consisted of five sowing lines spaced by 0.17 meters, with two meters in length, with useful area of $0.51 \mathrm{~m}^{2}$ from the two central lines.

Seeding was performed manually, in a direct system with population of 330 thousand viable seeds per hectare. Base fertilization and top dressing were performed according to the results of the previous soil analysis (CQFS-RS/SC, 2004). The control of diseases, weeds and pest insects were carried out in a preventive way, and the evaluations considered ten plants randomly sampled in the useful area of the experimental unit, being them:

Number of fertile tillers (NFT): measured by counting the number of fertile tiller per plant. Results were expressed in units.

Spike insertion height on the main plant (SIHMP): corresponds to the distance between the soil level and the spike insertion. The results were presented in centimeters.

Height of the main plant (HMP): determined by the plant that stands out from the others, measured by the distance between soil level and the last spikelet's apex. The results were presented in centimeters.

Spike insertion height of the main tiller (SIHMT): determined in the closest tiller to the main plant, which is higher than the others. For this, the distance between the ground level and the spike insertion was measured. The results were presented in centimeters.

Main tiller height (MTH): defined as the closest tiller to the main plant, measured by the distance between the soil level and the apex of the last spikelet. The results were presented in centimeters.

Spike insertion height of the secondary tiller (SIHST): The tiller closest to the main tiller was identified, and the distance between the ground level and spike insertion was determined. The results were presented in centimeters.

Height of secondary tiller (HST): considered the tiller closest to the main tiller, where the distance between the ground level and the last spikelet's apex was measured. The results were presented in centimeters.

The data were submitted to analysis of variance at $5 \%$ of probability to verify the assumptions of the statistical model (Ramalho et al., 2012). Subsequently, the interaction between wheat cultivars $\times$ seed lots $\times$ seed size was tested at $5 \%$ of probability. In the presence of significant interactions, the simple effects were sliced

\section{Results and Discussion}

Analysis of variance revealed significance for interaction between wheat cultivars $\times$ seed lots $\times$ seed size at 5\% probability for the traits number of fertile tiller (NFT), spike insertion height on the main plant (SIHMP), height of the main plant (HMP), spike insertion height of the main tiller (SIHMT), main tiller height (MTH), spike insertion height of the secondary tiller (SIHST) and height of secondary tiller (HST). 
Table 1. Physical and physiological characterization of seed lots. Germination (G), First germination count

\begin{tabular}{|c|c|c|c|c|c|c|c|c|c|c|c|c|c|}
\hline \multirow{3}{*}{ Cultivar } & \multirow{3}{*}{ Lot } & \multicolumn{12}{|c|}{ Width of the sieve's oblong hole } \\
\hline & & \multicolumn{3}{|c|}{$>3.0 \mathrm{~mm}$} & \multicolumn{3}{|c|}{2.5 to $2.99 \mathrm{~mm}$} & \multicolumn{3}{|c|}{2.0 to $2.49 \mathrm{~mm}$} & \multicolumn{3}{|c|}{$<2.00 \mathrm{~mm}$} \\
\hline & & $\begin{array}{l}\% \text { of seeds } \\
\text { in the lot }\end{array}$ & G\% & PCG \% & $\begin{array}{l}\% \text { of seeds } \\
\text { in the lot }\end{array}$ & $\mathrm{G} \%$ & $\mathrm{PCG} \%$ & $\begin{array}{l}\% \text { of seeds } \\
\text { in the lot }\end{array}$ & G \% & $\mathrm{PCG} \%$ & $\begin{array}{l}\% \text { of seeds } \\
\text { in the lot }\end{array}$ & G \% & PCG $\%$ \\
\hline Ametista & A & 6.08 & 83 & 78 & 36.02 & 88 & 80 & 52.52 & 82 & 73 & 5.38 & 78 & 66 \\
\hline Ametista & $\mathrm{B}$ & 2.70 & 86 & 81 & 55.13 & 89 & 84 & 37.11 & 83 & 78 & 5.06 & 81 & 67 \\
\hline Ametista & $\mathrm{C}$ & 3.81 & 83 & 81 & 55.98 & 90 & 86 & 36.11 & 87 & 80 & 4.1 & 83 & 77 \\
\hline Ametista & $\mathrm{D}$ & 1.69 & 45 & 37 & 24.33 & 56 & 49 & 67.21 & 73 & 63 & 6.77 & 70 & 58 \\
\hline Ametista & $\mathrm{E}$ & 1.74 & 48 & 37 & 26.66 & 49 & 39 & 65.94 & 65 & 52 & 5.66 & 70 & 58 \\
\hline Ametista & $\mathrm{F}$ & 1.95 & 37 & 28 & 27.62 & 49 & 37 & 68.76 & 53 & 42 & 1.67 & 61 & 49 \\
\hline Quartzo & A & 0.94 & 78 & 74 & 22.75 & 83 & 78 & 70.66 & 84 & 80 & 5.66 & 87 & 76 \\
\hline Quartzo & B & 0.97 & 73 & 61 & 23.11 & 69 & 62 & 70.2 & 67 & 58 & 5.72 & 68 & 57 \\
\hline Quartzo & $\mathrm{C}$ & 1.78 & 74 & 68 & 77.41 & 81 & 77 & 19.04 & 85 & 82 & 1.78 & 86 & 79 \\
\hline Quartzo & $\mathrm{D}$ & 5.29 & 92 & 91 & 62.11 & 94 & 93 & 27.89 & 91 & 88 & 4.72 & 94 & 91 \\
\hline Quartzo & E & 8.74 & 75 & 65 & 78.43 & 81 & 74 & 11.81 & 70 & 57 & 1.02 & 60 & 52 \\
\hline Quartzo & $\mathrm{F}$ & 3.27 & 77 & 66 & 70.9 & 76 & 59 & 20.43 & 71 & 63 & 5.41 & 75 & 65 \\
\hline Sinuelo & A & 4.58 & 81 & 80 & 67.31 & 79 & 78 & 26.89 & 86 & 85 & 1.22 & 88 & 84 \\
\hline Sinuelo & B & 2.72 & 86 & 80 & 67.16 & 86 & 86 & 26.63 & 90 & 87 & 3.49 & 89 & 86 \\
\hline Sinuelo & $\mathrm{C}$ & 3.76 & 70 & 62 & 81.70 & 85 & 82 & 12.52 & 86 & 82 & 2.03 & 82 & 78 \\
\hline Sinuelo & $\mathrm{D}$ & 2.92 & 95 & 90 & 76.82 & 94 & 92 & 17.18 & 89 & 85 & 3.08 & 80 & 76 \\
\hline Sinuelo & $\mathrm{E}$ & 7.45 & 95 & 94 & 72.51 & 94 & 94 & 15.50 & 90 & 89 & 4.54 & 80 & 67 \\
\hline Sinuelo & $\mathrm{F}$ & 3.68 & 80 & 77 & 32.61 & 90 & 89 & 48.55 & 92 & 89 & 15.16 & 88 & 87 \\
\hline
\end{tabular}

The number of fertile tiller (NFT) evidenced that sieve size does not present differences for cultivars Ametista and TBIO Sinuelo. However, plants of cultivar Quartzo from seeds retained in sieve IV (2.0 to $2.49 \mathrm{~mm}$ ) presented higher number of fertile tillers (Table 2). Among cultivars, Ametista was superior to the other cultivars tested in all sieve sizes. The emission of fertile tillers in wheat is related to yield components and productivity, being them influenced by plant density and intrinsic features of the cultivar used (Valério et al., 2008; Carvalho et al., 2017).

Among seed lots, the cultivar TBIO Sinuelo presented no difference for number of fertile tillers (NFT). The cultivar Ametista in lots E and F, as well as Quartzo in lot B, increased the number of fertile tillers. Among cultivars, the number of fertile tillers was higher for cultivar Quartzo in the seeds from lot B. For cultivar Ametista, it is evidenced in lot E. Considering the interaction between seed sizes $\times$ seed lots, lots $\mathrm{A}, \mathrm{C}$ and $\mathrm{D}$ showed no difference for number of fertile tillers (NFT) among sieve sizes used for standardization. However, lot B was superior through seeds of the sieve IV (2.0 to $2.49 \mathrm{~mm}$ ), as well as, lot $\mathrm{E}$ in sieve II (>3.0 mm), lot F in sieves II (> $3.0 \mathrm{~mm})$ and III $(2.5$ to $2.99 \mathrm{~mm})$, evidencing variability among seed sizes in the sampled lots.

Among lots, the number of fertile tillers (NFT) for seeds retained in the sieve V $(<2.0 \mathrm{~mm})$ did not vary among the evaluated lots, however, the original sample (OS) resulted in reduction of number of fertile tillers in $50 \%$ compared to the lots tested, sieve II (> $3.0 \mathrm{~mm}$ ) $66 \%$, sieve III $(2.5$ to $2.99 \mathrm{~mm}$ ) $16 \%$, and sieve IV (2.0 to 2.49 $\mathrm{mm}) 86 \%$ of the lots tested (Table 2). The difference in seed sizes and sampled lots may influence the response of the plant for emission and maintenance of the tillers throughout plant cycle, leading to significant effects on the number of reproductive structures per unit area, as well as for physiological quality of seeds produced (Ohlson et al., 2010). 
Table 2. Means for interaction between cultivars $\times$ seed sizes, cultivars $\times$ lots, and sieve sizes $\times$ lots for the trait number of fertile tillers (NFT)

\begin{tabular}{|c|c|c|c|c|c|c|c|c|c|c|}
\hline \multirow{3}{*}{$\begin{array}{l}\mathrm{SS}^{* *} \\
\mathrm{I}(\mathrm{OS})^{* * *}\end{array}$} & \multicolumn{10}{|c|}{ Number of fertile tillers } \\
\hline & \multicolumn{4}{|c|}{ Ametista } & \multicolumn{4}{|c|}{ Quartzo } & \multicolumn{2}{|c|}{ TBIO-Sinuelo } \\
\hline & \multicolumn{2}{|c|}{2.02} & \multicolumn{2}{|l|}{$\mathrm{aA}$} & \multicolumn{2}{|c|}{2.11} & \multicolumn{2}{|l|}{$\mathrm{bA}$} & 1.78 & $\mathrm{aA}$ \\
\hline $\mathrm{II}(>3.0 \mathrm{~mm})$ & \multicolumn{2}{|l|}{2.33} & \multicolumn{2}{|l|}{$\mathrm{aA}$} & \multicolumn{2}{|l|}{1.87} & \multicolumn{2}{|l|}{$\mathrm{bA}$} & 2.09 & $\mathrm{aA}$ \\
\hline III (2.5 to $2.99 \mathrm{~mm})$ & \multicolumn{2}{|l|}{2.33} & \multicolumn{2}{|l|}{$\mathrm{aA}$} & \multicolumn{2}{|l|}{1.79} & \multicolumn{2}{|l|}{$\mathrm{bB}$} & 2.11 & $\mathrm{aAB}$ \\
\hline IV (2.0 to $2.49 \mathrm{~mm})$ & \multicolumn{2}{|l|}{2.30} & \multicolumn{2}{|l|}{$\mathrm{aA}$} & \multicolumn{2}{|l|}{2.69} & \multicolumn{2}{|l|}{$\mathrm{aA}$} & 1.73 & $\mathrm{aB}$ \\
\hline $\mathrm{V}(<2.0 \mathrm{~mm})$ & \multicolumn{2}{|l|}{2.29} & \multicolumn{2}{|l|}{$\mathrm{aA}$} & \multicolumn{2}{|l|}{1.83} & \multicolumn{2}{|l|}{$\mathrm{bAB}$} & 1.69 & $\mathrm{aB}$ \\
\hline Lot & Ameti & & & & Quart & & & & TBIO-Sinuel & \\
\hline A & 1.88 & & $\mathrm{bA}$ & & 1.81 & & $\mathrm{bA}$ & & 1.57 & $\mathrm{aA}$ \\
\hline B & 1.96 & & $\mathrm{bB}$ & & 2.68 & & $\mathrm{aA}$ & & 1.65 & $\mathrm{aB}$ \\
\hline $\mathrm{C}$ & 2.28 & & $\mathrm{abA}$ & & 1.82 & & bA & & 2.09 & $\mathrm{aA}$ \\
\hline $\mathrm{D}$ & 2.34 & & $\mathrm{abA}$ & & 1.82 & & $\mathrm{bA}$ & & 2.00 & $\mathrm{aA}$ \\
\hline E & 2.62 & & $\mathrm{aA}$ & & 2.32 & & $\mathrm{abAB}$ & & 1.94 & $\mathrm{aB}$ \\
\hline $\mathrm{F}$ & 2.43 & & $\mathrm{aA}$ & & 1.90 & & $\mathrm{bA}$ & & 2.04 & $\mathrm{aA}$ \\
\hline SS** & Lot A & & Lot B & & Lot $\mathrm{C}$ & & Lot D & & Lot $\mathrm{E}$ & Lot $\mathrm{F}$ \\
\hline $\mathrm{I}(\mathrm{OS}) * * *$ & 1.64 & $\mathrm{aB}$ & 1.63 & $\mathrm{bB}$ & 2.20 & $\mathrm{aAB}$ & 2.29 & $\mathrm{aAB}$ & 2.47 & 1.60 \\
\hline $\mathrm{II}(>3.0 \mathrm{~mm})$ & 1.58 & $\mathrm{aB}$ & 2.03 & $\mathrm{bB}$ & 1.95 & $\mathrm{aB}$ & 1.78 & $\mathrm{aB}$ & 2.88 & 2.35 \\
\hline III (2.5 to $2.99 \mathrm{~mm})$ & 1.65 & $\mathrm{aB}$ & 1.75 & $\mathrm{bAB}$ & 2.17 & $\mathrm{aAB}$ & 2.11 & $\mathrm{aAB}$ & 2.38 & 2.38 \\
\hline IV (2.0 to $2.49 \mathrm{~mm})$ & 2.08 & $\mathrm{aB}$ & 3.31 & $\mathrm{aA}$ & 1.79 & $\mathrm{aB}$ & 2.20 & $\mathrm{aB}$ & 1.93 & 2.14 \\
\hline $\mathrm{V}(<2.0 \mathrm{~mm})$ & 1.81 & $\mathrm{aA}$ & 1.78 & $\mathrm{bA}$ & 2.22 & $\mathrm{aA}$ & 1.88 & $\mathrm{aA}$ & 1.77 & 2.15 \\
\hline $\mathrm{CV}(\%)$ & 36.9 & & & & & & & & & \\
\hline
\end{tabular}

Note. *Means followed by the same lowercase letter in the column, and the same capitalized letter in the row, do not statistically differ by Tukey at $5 \%$ of probability. ${ }^{* *}$ SS: Size of sieve and their respective seeds retained. *** OS: Original sample of the lot without size fractionation.

The spike insertion height on the main plant (SIHMP) presented variability for the cultivars (Table 3). For cultivar Ametista, plants originated from the original sample (OS) obtained lower spike insertion height of main plant through lots B and D, as well as plants originated from seeds retained in the sieve IV (2.0 to $2.49 \mathrm{~mm}$ ) for lots D and F, and sieve V $(<2.00 \mathrm{~mm})$ for lot D. For cultivar Quartzo, seeds retained in the sieve III (2.5 to 2.99 $\mathrm{mm}$ ) presented inferiority through lots A and F, as well as the sieve $\mathrm{V}(<2.00 \mathrm{~mm})$ for lots $\mathrm{B}, \mathrm{C}, \mathrm{D}, \mathrm{E}$ and F. For cultivar Sinuelo, the original sample (OS) presented lower spike insertion height of the main plant through lot D, as well as sieve II $(>3.0 \mathrm{~mm})$ for lots $\mathrm{C}$ and $\mathrm{E}$, sieve IV $(2.0$ to $2.49 \mathrm{~mm})$ for lot $\mathrm{B}$, and sieve $\mathrm{V}(<2.0 \mathrm{~mm})$ for lot E.

Lower plants are related to less foliar area and growth (Collares et al., 2008), however, they may present lodging tolerance (Espindula et al., 2010), which is related to photoassimilates translocation, grain mass, and consequently grain yield (Silva et al., 2006).

Among the lots, there were differences between sizes and cultivars studied. For the cultivar Ametista, the seeds retained in sieve II (> $3.0 \mathrm{~mm})$ and III $(2.5$ to $2.99 \mathrm{~mm})$ obtained lower magnitude in $16 \%$ of the evaluated lots, as well as the sieve IV (2.0 to $2.49 \mathrm{~mm})$ in $50 \%$ of the lots, and sieve V $(<2.00 \mathrm{~mm})$ in $33 \%$ of the lots. The cultivar Quartzo, under nonstandard conditions of the seeds (OS), presented lower spike insertion height in 16\% of the evaluated lots, as well as the seeds retained in sieve IV $(2.0$ to $2.49 \mathrm{~mm})$ in $33 \%$ of the lots. Regarding the cultivar TBIO Sinuelo, the seeds from original sample (OS), seeds retained in sieve III (2.5 to $2.99 \mathrm{~mm}$ ) and IV $(2.0$ to $2.49 \mathrm{~mm})$ as well as sieve II $(>3.0 \mathrm{~mm})$, and V $(<2.0 \mathrm{~mm})$ in $16 \%$ of the evaluated lots. Therefore, for these cultivars, there are variations in response to sieves used for standardization, as function of the lot sampled and seed production environment. The morphological traits of wheat are affected by genetic characteristics (Carvalho et al., 2016) and competition among plants (Ferreira et al., 2008).

The height of the main plant (HMP) differed among lots and seed sizes, while in plants originated from cultivar Ametista, the sieves used for seed standardization did not influence the performance of lots A, C and E (Table 3). However, the non-standardized seeds from the original sample (OS) of lot B, sieve III (2.5 to $2.99 \mathrm{~mm})$ of lot D, and sieve IV (2.0 to $2.49 \mathrm{~mm}$ ) of lot F, resulted in smaller plants (HMP). For cultivar Quartzo, seed size did not influence the height of main plant (HMP) in lot F, but in lot A, the seeds retained in the sieve III (2.5 to 2.99 $\mathrm{mm})$, lot C, in sieve IV $(2.0$ to $2.49 \mathrm{~mm})$ and V $(>2.0 \mathrm{~mm})$, and sieve $\mathrm{V}(>2.0 \mathrm{~mm})$ of lots B, D and E presented reduction in plant height. Regarding the cultivar TBIO Sinuelo, lots A, D and E did not reveal differences for 
height of the main plant according to seed standardization. However, the seeds retained in sieve II $(>3.0 \mathrm{~mm})$ presented lower height of the main plant in lots $\mathrm{C}$ and $\mathrm{E}$, as well as the sieve IV (2.0 to $2.49 \mathrm{~mm}$ ) and V (> 2.0 $\mathrm{mm}$ ) of lot B.

Table 3. Means for interaction among cultivars $\times$ seed sizes $\times$ lots for the traits spike insertion height on the main plant (SIHMP), and height of the main plant (HMP)

\begin{tabular}{|c|c|c|c|c|c|c|c|c|c|c|c|c|}
\hline \multicolumn{13}{|c|}{ Spike insertion height on the main plant $(\mathrm{cm})$} \\
\hline \multirow{2}{*}{$\mathrm{SS}^{* *}$} & \multicolumn{12}{|c|}{ Ametista } \\
\hline & Lot A & & Lot B & & Lot $\mathrm{C}$ & & Lot D & & Lot E & & Lot $\mathrm{F}$ & \\
\hline $\mathrm{I}(\mathrm{OS}) * * *$ & 89.90 & $\mathrm{aA} \alpha$ & 86.06 & $\mathrm{bA} \beta$ & 90.53 & $\mathrm{aA} \beta$ & 88.00 & $\mathrm{bA} \beta$ & 91.63 & $\mathrm{aA} \alpha$ & 91.36 & $\mathrm{aA} \alpha$ \\
\hline $\mathrm{II}(>3.0 \mathrm{~mm})$ & 87.90 & $\mathrm{aB} \alpha$ & 92.11 & $\mathrm{aA} \alpha$ & 89.96 & $\mathrm{aAB} \alpha$ & 93.07 & $\mathrm{aA} \alpha$ & 90.96 & $\mathrm{aAB} \alpha$ & 90.43 & $\mathrm{aAB} \alpha$ \\
\hline III (2.5 to $2.99 \mathrm{~mm})$ & 90.83 & $\mathrm{aAB} \alpha$ & 92.60 & $\mathrm{aAB} \alpha$ & 86.87 & $\mathrm{aC} \beta$ & 89.26 & $\mathrm{abBC} \alpha$ & 94.43 & $\mathrm{aA} \alpha$ & 90.60 & $\mathrm{aABC} \alpha$ \\
\hline IV (2.0 to $2.49 \mathrm{~mm})$ & 89.03 & $\mathrm{aAB} \beta$ & 89.60 & $\mathrm{abAB} \alpha$ & 88.76 & $\mathrm{aB} \alpha$ & 88.03 & $\mathrm{bB} \alpha$ & 92.80 & $\mathrm{aA} \alpha$ & 86.23 & $\mathrm{bB} \alpha \beta$ \\
\hline $\mathrm{V}(<2.0 \mathrm{~mm})$ & 87.38 & $\mathrm{aB} \beta$ & 88.71 & $\mathrm{abAB} \alpha$ & 88.23 & $\mathrm{aB} \alpha$ & 88.73 & $\mathrm{bAB} \alpha$ & 90.83 & $\mathrm{aAB} \alpha$ & 91.45 & $\mathrm{aA} \alpha$ \\
\hline \multirow{2}{*}{$\mathrm{SS}^{* *}$} & \multicolumn{12}{|c|}{ Quartzo } \\
\hline & Lot A & & Lot B & & Lot C & & Lot D & & Lot $\mathrm{E}$ & & Lot $F$ & \\
\hline $\mathrm{I}(\mathrm{OS})^{* * *}$ & 92.56 & $\mathrm{aAB} \alpha$ & 92.05 & $\mathrm{aAB} \alpha$ & 95.60 & $\mathrm{aA} \alpha$ & 94.70 & $\mathrm{aAB} \alpha$ & 91.13 & $\mathrm{aBC} \alpha \beta$ & 87.58 & $\mathrm{bC} \alpha$ \\
\hline $\mathrm{II}(>3.0 \mathrm{~mm})$ & 91.70 & $\mathrm{aA} \alpha$ & 90.11 & $\mathrm{abA} \alpha$ & 92.48 & $\mathrm{abA} \alpha$ & 93.83 & $\mathrm{abA} \alpha$ & 92.20 & $\mathrm{aA} \alpha$ & 91.86 & $\mathrm{aA} \alpha$ \\
\hline III (2.5 to $2.99 \mathrm{~mm})$ & 87.52 & $\mathrm{bA} \alpha$ & 88.98 & $\mathrm{abA} \alpha$ & 91.03 & $\mathrm{bA} \alpha$ & 90.13 & $\mathrm{bcA} \alpha$ & 91.43 & $\mathrm{aA} \alpha \beta$ & 87.53 & $\mathrm{bA} \alpha$ \\
\hline IV (2.0 to $2.49 \mathrm{~mm})$ & 93.73 & $\mathrm{aA} \alpha$ & 91.96 & $\mathrm{aAB} \alpha$ & 89.26 & $\mathrm{bcB} \alpha$ & 89.16 & $\operatorname{cdB} \alpha$ & 91.31 & $\mathrm{aAB} \alpha$ & 89.86 & $\mathrm{abAB} \alpha$ \\
\hline $\mathrm{V}(<2.0 \mathrm{~mm})$ & 95.31 & $\mathrm{aA} \alpha$ & 87.35 & $\mathrm{bB} \alpha$ & 87.32 & $\mathrm{cB} \alpha$ & 85.93 & $\mathrm{~dB} \alpha$ & 86.23 & $\mathrm{bB} \beta$ & 87.46 & $\mathrm{bB} \beta$ \\
\hline \multirow{2}{*}{$\mathrm{SS}^{* *}$} & \multicolumn{12}{|c|}{ TBIO Sinuelo } \\
\hline & Lot A & & Lot B & & Lot $\mathrm{C}$ & & Lot D & & Lot $\mathrm{E}$ & & Lot $\mathrm{F}$ & \\
\hline $\mathrm{I}(\mathrm{OS}) * * *$ & 85.86 & $\mathrm{aAB} \beta$ & 87.98 & $\mathrm{aA} \beta$ & 87.36 & $\mathrm{abA} \beta$ & 83.31 & $\mathrm{bB} \Gamma$ & 87.66 & $\mathrm{aA} \beta$ & 83.28 & $\mathrm{aB} \beta$ \\
\hline $\mathrm{II}(>3.0 \mathrm{~mm})$ & 89.63 & $\mathrm{aA} \alpha$ & 87.30 & $\mathrm{abAB} \beta$ & 84.84 & $\mathrm{bBC} \beta$ & 86.96 & $\mathrm{abABC} \beta$ & 81.48 & $\mathrm{bD} \beta$ & 83.26 & $\mathrm{aCD} \beta$ \\
\hline III ( 2.5 to $2.99 \mathrm{~mm})$ & 88.10 & $\mathrm{aAB} \alpha$ & 89.90 & $\mathrm{aA} \alpha$ & 89.73 & $\mathrm{aA} \alpha \beta$ & 84.90 & $\mathrm{abB} \beta$ & 88.20 & $\mathrm{aAB} \beta$ & 84.63 & $\mathrm{aB} \beta$ \\
\hline IV (2.0 to $2.49 \mathrm{~mm})$ & 87.83 & $\mathrm{aA} \beta$ & 83.33 & $\mathrm{cB} \beta$ & 87.00 & $\mathrm{abAB} \alpha$ & 87.10 & $\mathrm{abAB} \alpha$ & 86.27 & $\mathrm{aA} \beta$ & 85.83 & $\mathrm{aB} \beta$ \\
\hline $\mathrm{V}(<2.0 \mathrm{~mm})$ & 88.86 & $\mathrm{aA} \beta$ & 83.41 & $\mathrm{bcBC} \beta$ & 86.80 & $\mathrm{abAB} \alpha$ & 87.63 & $\mathrm{aA} \alpha$ & 82.20 & $\mathrm{bC} \Gamma$ & 86.88 & $\mathrm{aAB} \beta$ \\
\hline $\mathrm{CV}(\%)$ & 8.72 & & & & & & & & & & & \\
\hline \multicolumn{13}{|c|}{ Height of the main plant $(\mathrm{cm})$} \\
\hline \multirow{2}{*}{$\mathrm{SS}^{* *}$} & \multicolumn{12}{|c|}{ Ametista } \\
\hline & Lot A & & Lot B & & Lot $\mathrm{C}$ & & Lot D & & Lot E & & Lot $\mathrm{F}$ & \\
\hline $\mathrm{I}(\mathrm{OS}) * * *$ & 97.11 & $\mathrm{aA} \alpha$ & 93.10 & $\mathrm{bA} \alpha$ & 97.93 & $\mathrm{aA} \alpha \beta$ & 94.53 & $\mathrm{abA} \beta$ & 100.3 & $\mathrm{aA} \alpha$ & 98.50 & $\mathrm{aA} \alpha$ \\
\hline $\mathrm{II}(>3.0 \mathrm{~mm})$ & 95.16 & $\mathrm{aA} \alpha$ & 96.32 & $\mathrm{abA} \alpha$ & 97.36 & $\mathrm{aA} \alpha$ & 99.46 & $\mathrm{aA} \alpha$ & 99.53 & $\mathrm{aA} \alpha$ & 99.53 & $\mathrm{aA} \alpha$ \\
\hline III (2.5 to $2.99 \mathrm{~mm})$ & 94.66 & $\mathrm{aB} \alpha$ & 100.08 & $\mathrm{aA} \alpha$ & 93.66 & $\mathrm{aB} \alpha$ & 93.03 & $b B \alpha \beta$ & 102.26 & $\mathrm{aA} \alpha$ & 98.06 & $\mathrm{aAB} \alpha$ \\
\hline IV (2.0 to $2.49 \mathrm{~mm})$ & 96.43 & $\mathrm{aAB} \beta$ & 96.83 & $\mathrm{abAB} \alpha$ & 96.39 & $\mathrm{aAB} \alpha$ & 95.55 & $\mathrm{abAB} \alpha$ & 99.86 & $\mathrm{aA} \alpha$ & 93.00 & $\mathrm{bB} \alpha$ \\
\hline $\mathrm{V}(<2.0 \mathrm{~mm})$ & 94.75 & $\mathrm{aA} \beta$ & 96.64 & $\mathrm{abA} \alpha$ & 95.73 & $\mathrm{aA} \alpha$ & 93.36 & $\mathrm{abA} \alpha$ & 98.36 & $\mathrm{aA} \alpha$ & 96.42 & $\mathrm{abA} \alpha$ \\
\hline \multirow{2}{*}{$\mathrm{SS}^{* *}$} & \multicolumn{12}{|c|}{ Quartzo } \\
\hline & Lot A & & Lot B & & Lot $\mathrm{C}$ & & Lot D & & Lot E & & Lot $\mathrm{F}$ & \\
\hline $\mathrm{I}(\mathrm{OS})^{* * *}$ & 98.73 & $\mathrm{abA} \alpha$ & 96.53 & $\mathrm{abA} \alpha$ & 101.95 & $\mathrm{aA} \alpha$ & 101.90 & $\mathrm{aA} \alpha$ & 99.33 & $\mathrm{aA} \alpha \beta$ & 94.50 & $\mathrm{aA} \alpha \beta$ \\
\hline $\mathrm{II}(>3.0 \mathrm{~mm})$ & 98.43 & $\mathrm{abA} \alpha$ & 96.36 & $\mathrm{abA} \alpha$ & 98.68 & $\mathrm{abA} \alpha$ & 100.48 & $\mathrm{abA} \alpha$ & 98.60 & $\mathrm{abA} \alpha$ & 99.03 & $\mathrm{aA} \alpha$ \\
\hline III (2.5 to $2.99 \mathrm{~mm})$ & 95.42 & $\mathrm{bA} \alpha$ & 95.67 & $\mathrm{abA} \alpha$ & 97.76 & $\mathrm{abA} \alpha$ & 97.66 & $\mathrm{abA} \alpha$ & 99.06 & $\mathrm{aA} \alpha \beta$ & 95.16 & $\mathrm{aA} \alpha \beta$ \\
\hline IV ( 2.0 to $2.49 \mathrm{~mm})$ & 103.53 & $\mathrm{aA} \alpha$ & 99.76 & $\mathrm{aAB} \alpha$ & 96.36 & $\mathrm{bB} \alpha$ & 96.73 & $\mathrm{bB} \alpha$ & 98.74 & $\mathrm{aAB} \alpha \beta$ & 97.53 & $\mathrm{aB} \alpha$ \\
\hline $\mathrm{V}(<2.0 \mathrm{~mm})$ & 102.82 & $\mathrm{aA} \alpha$ & 94.04 & $\mathrm{bBC} \alpha \beta$ & 95.01 & $\mathrm{bBC} \alpha$ & 90.23 & $\mathrm{cC} \alpha$ & 93.53 & $\mathrm{bBC} \alpha \beta$ & 95.86 & $\mathrm{aB} \alpha$ \\
\hline \multirow{2}{*}{$\mathrm{SS}^{* *}$} & \multicolumn{12}{|c|}{ TBIO Sinuelo } \\
\hline & Lot A & & Lot B & & Lot C & & Lot D & & Lot E & & Lot $\mathrm{F}$ & \\
\hline $\mathrm{I}(\mathrm{OS}) * * *$ & 93.06 & $\mathrm{aA} \alpha$ & 95.91 & $\mathrm{aA} \alpha$ & 94.36 & $\mathrm{abA} \beta$ & 90.82 & $\mathrm{aAB} \beta$ & 94.93 & $\mathrm{aA} \beta$ & 89.87 & $\mathrm{aB} \beta$ \\
\hline $\mathrm{II}(>3.0 \mathrm{~mm})$ & 97.46 & $\mathrm{aA} \alpha$ & 94.50 & $\mathrm{abA} \alpha$ & 91.54 & $\mathrm{bA} \beta$ & 93.15 & $\mathrm{aA} \beta$ & 82.22 & $\mathrm{cB} \beta$ & 95.03 & $\mathrm{aA} \alpha$ \\
\hline III ( 2.5 to $2.99 \mathrm{~mm})$ & 97.16 & $\mathrm{aA} \alpha$ & 97.36 & $\mathrm{aA} \alpha$ & 97.3 & $\mathrm{aA} \alpha$ & 92.16 & $\mathrm{aB} \beta$ & 94.73 & $\mathrm{aAB} \beta$ & 92.16 & $\mathrm{aB} \beta$ \\
\hline IV (2.0 to $2.49 \mathrm{~mm})$ & 95.08 & $\mathrm{aA} \beta$ & 90.43 & $\mathrm{bA} \beta$ & 94.36 & $\mathrm{abA} \alpha$ & 94.40 & $\mathrm{aA} \alpha$ & 93.72 & $\mathrm{abA} \beta$ & 93.3 & $\mathrm{aA} \alpha$ \\
\hline $\mathrm{V}(<2.0 \mathrm{~mm})$ & 95.75 & $\mathrm{aA} \beta$ & 90.25 & $\mathrm{bB} \beta$ & 94.28 & $\mathrm{abAB} \alpha$ & 94.13 & $\mathrm{aAB} \alpha$ & 89.24 & $\mathrm{bB} \beta$ & 94.22 & $\mathrm{aAB} \alpha$ \\
\hline $\mathrm{CV}(\%)$ & 10.56 & & & & & & & & & & & \\
\hline
\end{tabular}

Note. *Means followed by the same lowercase letter in the column for sieve sizes, the same capitalized letter in the row for seed size between lots, and the same Greek letter between cultivars did not statistically differ by Tukey at $5 \%$ of probability of error. $* *$ SS: Size of sieve and their respective seeds retained. ${ }^{* *}$ OS: Original sample of the lot without size fractionation. 
Among lots of the cultivar Ametista, plants from non-standardized seeds (OS), from seeds retained in sieves II (> $3.0 \mathrm{~mm})$ and $\mathrm{V}(>2.0 \mathrm{~mm})$ did not affect the height of the main plant. However, (2.5 to $2.99 \mathrm{~mm})$ hole diameter negatively influenced this character in $50 \%$ of the lots, as well as sieve IV (2.0 to $2.49 \mathrm{~mm}$ ) influenced $16 \%$ of the lots evaluated. For cultivar Quartzo, the seeds from the original sample (OS) without standardization, and seeds retained in sieve II (>3.0 mm) and III $(2.5$ to $2.99 \mathrm{~mm})$ did not differ in the HMP, but seeds from sieves IV ( 2.0 to $2.49 \mathrm{~mm}$ ) and $\mathrm{V}(>2.0 \mathrm{~mm}$ ) negatively affect this trait in $66 \%$ and $16 \%$ of the evaluated lots, respectively. Regarding the cultivar TBIO Sinuelo, lots A, D and E showed no difference between seed sizes. However, plants from the original sample (OS), and seeds retained in sieve II $(>3.0 \mathrm{~mm})$ had a negative influence on main plant height (MPH) of $16 \%$ of the evaluated lots, as well as seeds retained in the sieve III (2.5 to $2.99 \mathrm{~mm}$ ) and V (< $2.0 \mathrm{~mm}$ ) reduced main plant height in $33 \%$ of the lots studied.

Plants with shorter height may decrease lodging and contribution to increase length and number of spikelets, spike weight and number of grains per spike (Silva et al., 2006). However, these plants may result in negative effects for inflorescence dimensions (Harwig et al., 2006) and seed mass (Espindula et al., 2010).

Among genotypes, there was superiority for cultivar Quartzo regarding spike insertion height on the main plant (SIHMP), (Table 3), as well as the cultivars Ametista and Quartzo (Table 4) for spike insertion height on the main tiller (SIHMT), main tiller height (MTH). The spike insertion height of the main tiller (SIHMT) determined that plants from cultivar Ametista of lots $\mathrm{C}$ and D did not show influence of seed size. However, the seeds retained in sieves II (>3.0 mm) of the lot A, original sample (OS) of lot B, sieve IV (2.0 to $2.49 \mathrm{~mm})$ and V (< $2.0 \mathrm{~mm}$ ) from lot E, original sample (OS) and sieve IV $(2.0$ to $2.49 \mathrm{~mm})$ of lot $\mathrm{F}$, had lower insertion height of the main tiller (SIHMT). Plants from larger seeds emerge faster and increase their height (Chastain et al., 1994). Among the lots, plants originated from seeds of the non-standardized original sample (OS) had negative effect on spike insertion height of the main tiller (SIHMT) in 33\% of the lots studied, as well as the seeds retained in the sieves II $(>3.00 \mathrm{~mm})$, III $(2.5$ to $2.99 \mathrm{~mm})$, IV $(2.0$ to $2.49 \mathrm{~mm})$ and V $(<2.0 \mathrm{~mm})$ in $16 \%$ of the lots evaluated.

For the cultivar Quartzo, the standardization did not differ in lot E. However, plants from seeds retained in sieve III (2.5 to $2.99 \mathrm{~mm})$ of lot A, sieve V $(<2.0 \mathrm{~mm})$ of lots B and C, sieve II $(>3.0 \mathrm{~mm})$ and $\mathrm{V}(<2.0 \mathrm{~mm})$ of lot D, non-standardized original sample (OS) of lot $\mathrm{F}$ presented lower spike insertion height of the maim tiller (SIHMT). Among the lots, seeds from sieves II $(>3.0 \mathrm{~mm})$ and IV $(2.0$ to $2.49 \mathrm{~mm})$ did not differ, however, from the original sample $(\mathrm{OS})$ and sieve III $(2.5$ to $2.99 \mathrm{~mm})$ revealed that $16 \%$ of the lots, as well as sieve V $(<$ $2.0 \mathrm{~mm}$ ) with $66 \%$ of the lots presented lower values for this trait.

It is possible to enhance the quality of a seed lot through standardization, since the variation of seed size of this lot influences seedling growth and uniformity (Sainio et al., 2011), because lots without standardization process present different physical characteristics (Ormond et al., 2013) and can express differential field performance.

Regarding the cultivar TBIO Sinuelo, the standardization had no influence on lot $\mathrm{C}$ for spike insertion height of the main tiller (SIHMT). Considering plants from seeds of the sieve IV (2.0 to $2.49 \mathrm{~mm}$ ) for lot A, original sample (OS) without standardization, sieve III $(2.5$ to $2.99 \mathrm{~mm})$, IV $(2.0$ to 2.49$)$, and sieve V $(<2.0 \mathrm{~mm})$ from lot $\mathrm{B}$, original sample $(\mathrm{OS})$ from lots $\mathrm{D}$ and $\mathrm{F}$, and plants originating from sieve $\mathrm{V}(<2.0 \mathrm{~mm})$ of lot $\mathrm{E}$, showed inferior magnitude. Among lots, the plants from sieve II $(>3.0 \mathrm{~mm})$ did not differ, however, original sample (OS), sieves III ( 2.5 to $2.99 \mathrm{~mm})$, and V $(<2.0 \mathrm{~mm})$ influenced negatively in $33 \%$ of the lots, and the plants from sieve IV (2.0 to $2.49 \mathrm{~mm}$ ) in $50 \%$ of the evaluated lots.

The spike insertion height of the main tiller (SIHMT) varied among lots and cultivars, with tendency that larger seeds provided higher plants, with higher spike insertion height (Sainio et al., 2011), showing the presence of variability between lots evaluated and the need of using sieves for wheat seeds standardization in order to achieve lots more uniform at field.

The main tiller height (MTH) (Table 4) for cultivar Ametista, showed that lots C and D were not influenced by seed standardization. However, plants originated from seeds retained in the sieve II ( $>3.0 \mathrm{~mm}$ ) of lot A, original sample (OS) of lot $\mathrm{B}$, and seeds retained in sieve $\mathrm{V}(<2.0 \mathrm{~mm})$ of lot $\mathrm{C}$, original sample (OS) and sieve IV (2.0 to $2.49 \mathrm{~mm}$ ) from lot $\mathrm{F}$ presented lower height of the main tiller. Among the lots, seeds from sieves II ( $>3.0 \mathrm{~mm})$ and IV (2.0 to $2.49 \mathrm{~mm}$ ) did not differ, but the original sample (OS) and plants from seeds of the sieve III ( 2.5 to $2.99 \mathrm{~mm}$ ) negatively influenced the height of the main plant in $16 \%$ of the lots, and by the sieve $\mathrm{V}(<2.0 \mathrm{~mm})$ in $66 \%$ of the lots studied. 
Table 4. Means for interaction among cultivars $\times$ seed sizes $\times$ lots for the traits spike insertion height of the main tiller (SIHMT), and main tiller height (MTH)

\begin{tabular}{|c|c|c|c|c|c|c|c|c|c|c|c|c|}
\hline \multicolumn{13}{|c|}{ Spike insertion height of the main tiller $(\mathrm{cm})$} \\
\hline \multirow{2}{*}{$\mathrm{SS}^{* *}$} & \multicolumn{12}{|c|}{ Ametista } \\
\hline & Lot A & & Lot B & & Lot $\mathrm{C}$ & & Lot D & & Lot E & & Lot $\mathrm{F}$ & \\
\hline $\mathrm{I}(\mathrm{OS})^{* * *}$ & 78.73 & $\mathrm{aA} \alpha$ & 65.36 & $\mathrm{bB} \alpha$ & 71.50 & $\mathrm{aAB} \alpha$ & 74.90 & $\mathrm{aAB} \alpha \beta$ & 81.13 & $\mathrm{abA} \alpha$ & 63.66 & $\mathrm{bB} \alpha$ \\
\hline $\mathrm{II}(>3.0 \mathrm{~mm})$ & 61.60 & $\mathrm{bB} \alpha$ & 80.28 & $\mathrm{aA} \alpha$ & 80.43 & $\mathrm{aA} \alpha$ & 75.52 & $\mathrm{aAB} \alpha$ & 83.73 & $\mathrm{abA} \alpha$ & 76.00 & $\mathrm{abAB} \alpha$ \\
\hline III (2.5 to $2.99 \mathrm{~mm})$ & 78.60 & $\mathrm{aAB} \alpha$ & 82.63 & $\mathrm{aAB} \alpha$ & 73.33 & $\mathrm{aB} \alpha$ & 74.30 & $\mathrm{aAB} \alpha$ & 88.50 & $\mathrm{aA} \alpha$ & 78.03 & $\mathrm{abAB} \alpha$ \\
\hline IV $(2.0$ to $2.49 \mathrm{~mm})$ & 73.53 & $\mathrm{abAB} \alpha \beta$ & 82.63 & $\mathrm{aA} \alpha$ & 68.30 & $\mathrm{aAB} \alpha$ & 74.30 & $\mathrm{aAB} \alpha$ & 73.20 & $\mathrm{bAB} \alpha \beta$ & 64.30 & $\mathrm{bB} \beta$ \\
\hline $\mathrm{V}(<2.0 \mathrm{~mm})$ & 69.30 & $\mathrm{abB} \beta$ & 73.53 & $\mathrm{abAB} \alpha$ & 80.00 & $\mathrm{aAB} \alpha$ & 81.80 & $\mathrm{aAB} \alpha$ & 72.36 & $\mathrm{bAB} \alpha$ & 86.28 & $\mathrm{aA} \alpha$ \\
\hline \multirow{2}{*}{$\mathrm{SS}^{* *}$} & \multicolumn{12}{|c|}{$\begin{array}{l}\text { Quartzo } \\
\end{array}$} \\
\hline & Lot A & & Lot B & & Lot $\mathrm{C}$ & & Lot D & & Lot $\mathrm{E}$ & & Lot F & \\
\hline $\mathrm{I}(\mathrm{OS})^{* * *}$ & 72.93 & $\mathrm{bBC} \alpha$ & 71.71 & $\mathrm{abBC} \alpha$ & 83.9 & $\mathrm{aAB} \alpha$ & 88.33 & $\mathrm{aA} \alpha$ & 83.33 & $\mathrm{aAB} \alpha$ & 60.15 & $\mathrm{bC} \alpha$ \\
\hline $\mathrm{II}(>3.0 \mathrm{~mm})$ & 74.23 & $\mathrm{bA} \alpha$ & 78.66 & $\mathrm{abA \alpha}$ & 72.99 & $\mathrm{abA} \alpha$ & 70.54 & $\mathrm{bA} \alpha$ & 80.73 & $\mathrm{aA} \alpha$ & 79.6 & $\mathrm{aA} \alpha$ \\
\hline III (2.5 to $2.99 \mathrm{~mm})$ & 49.87 & $\mathrm{cB} \beta$ & 73.19 & $a b A \alpha \beta$ & 79.26 & $\mathrm{abA} \alpha$ & 77.06 & $\mathrm{abA} \alpha$ & 76.46 & $\mathrm{aA} \alpha \beta$ & 75.26 & $\mathrm{aA} \alpha$ \\
\hline IV (2.0 to $2.49 \mathrm{~mm})$ & 84.33 & $\mathrm{abA} \alpha$ & 83.7 & $\mathrm{aA} \alpha$ & 78.3 & $\mathrm{abA} \alpha$ & 75.8 & $\mathrm{abA} \alpha$ & 82.99 & $\mathrm{aA} \alpha$ & 78.1 & $\mathrm{aA} \alpha$ \\
\hline $\mathrm{V}(<2.0 \mathrm{~mm})$ & 89.99 & $\mathrm{aA} \alpha$ & 65.67 & $\mathrm{bB} \alpha$ & 67.01 & $\mathrm{bB} \alpha$ & 66.06 & $\mathrm{bB} \beta$ & 68.96 & $\mathrm{aB} \alpha$ & 78.1 & $\mathrm{aAB} \alpha \beta$ \\
\hline \multirow{2}{*}{$\mathrm{SS} * *$} & \multicolumn{12}{|c|}{ TBIO Sinuelo } \\
\hline & \multicolumn{2}{|l|}{ Lot A } & \multicolumn{2}{|l|}{ Lot B } & Lot $\mathrm{C}$ & & \multicolumn{2}{|c|}{ Lot D } & \multicolumn{2}{|l|}{ Lot E } & \multicolumn{2}{|l|}{ Lot F } \\
\hline $\mathrm{I}(\mathrm{OS})^{* * *}$ & 66.01 & $\mathrm{abBC} \alpha$ & 60.64 & $\mathrm{bC} \alpha$ & 75.8 & $\mathrm{aAB} \alpha$ & 64.3 & $\mathrm{bBC} \beta$ & 82.63 & $\operatorname{Aa} \alpha$ & 59.17 & $\mathrm{bC} \alpha$ \\
\hline $\mathrm{II}(>3.0 \mathrm{~mm})$ & 70.43 & $\mathrm{abA} \alpha$ & 79.00 & $\mathrm{aA} \alpha$ & 77.71 & $\mathrm{aA} \alpha$ & 76.18 & $\mathrm{abA} \alpha$ & 74.69 & $\mathrm{abA} \alpha$ & 81.03 & $\mathrm{aA} \alpha$ \\
\hline III (2.5 to $2.99 \mathrm{~mm})$ & 79.70 & $\mathrm{aA} \alpha$ & 63.53 & $\mathrm{bB} \beta$ & 75.73 & $\mathrm{aAB} \alpha$ & 76.43 & $\mathrm{abAB} \alpha$ & 68.56 & $\mathrm{abcAB} \beta$ & 73.66 & $\mathrm{abAB} \alpha$ \\
\hline IV (2.0 to $2.49 \mathrm{~mm})$ & 63.59 & $\mathrm{bB} \beta$ & 61.83 & $b B \beta$ & 64.06 & $\mathrm{aB} \alpha$ & 80.60 & $\mathrm{aA} \alpha$ & 67.92 & $\mathrm{bcAB} \beta$ & 71.13 & $\mathrm{abAB} \alpha \beta$ \\
\hline $\mathrm{V}(<2.0 \mathrm{~mm})$ & 72.48 & $\mathrm{abAB} \beta$ & 62.54 & $\mathrm{bB} \alpha$ & 77.9 & $\mathrm{aA} \alpha$ & 73.06 & $\mathrm{abAB} \alpha \beta$ & 59.63 & $\mathrm{cB} \alpha$ & 68.46 & $\mathrm{abAB} \beta$ \\
\hline & 10.56 & & & & & & & & & & & \\
\hline \multicolumn{13}{|c|}{ Main tiller height (cm) } \\
\hline \multirow{2}{*}{$\mathrm{SS}^{* *}$} & \multicolumn{12}{|c|}{ Ametista } \\
\hline & Lot A & & Lot B & & Lot $\mathrm{C}$ & & Lot D & & Lot E & & Lot F & \\
\hline $\mathrm{I}(\mathrm{OS}) * * *$ & 85.15 & $\mathrm{aA} \alpha$ & 70.90 & $\mathrm{bAB} \alpha$ & 76.96 & $\mathrm{aAB} \alpha$ & 80.73 & $\mathrm{aAB} \alpha \beta$ & 84.56 & $\mathrm{abA} \alpha$ & 68.73 & $\mathrm{bB} \alpha$ \\
\hline $\mathrm{II}(>3.0 \mathrm{~mm})$ & 66.30 & $\mathrm{bB} \alpha$ & 86.59 & $\mathrm{abA} \alpha$ & 87.23 & $\mathrm{aA} \alpha$ & 81.81 & $\mathrm{aAB} \alpha$ & 90.50 & $\mathrm{abA} \alpha$ & 82.0 & $\mathrm{abAB} \alpha$ \\
\hline III (2.5 to $2.99 \mathrm{~mm})$ & 84.26 & $\mathrm{aAB} \alpha$ & 88.80 & $\mathrm{aAB} \alpha$ & 79.66 & $\mathrm{aB} \alpha$ & 81.03 & $\mathrm{aAB} \alpha$ & 95.93 & $\mathrm{aA} \alpha$ & 84.23 & $\mathrm{abAB} \alpha$ \\
\hline IV (2.0 to $2.49 \mathrm{~mm})$ & 78.35 & $\mathrm{abAB} \alpha \beta$ & 89.80 & $\mathrm{aA} \alpha$ & 74.08 & $\mathrm{aAB} \alpha$ & 80.90 & $\mathrm{aAB} \alpha$ & 78.96 & $\operatorname{Bab} \alpha \beta$ & 71.60 & $\mathrm{bB} \alpha$ \\
\hline $\mathrm{V}(<2.0 \mathrm{~mm})$ & 75.15 & $\mathrm{abB} \beta$ & 78.74 & $\mathrm{abAB} \alpha$ & 86.55 & $\mathrm{aAB} \alpha$ & 85.53 & $\mathrm{aAB} \alpha$ & 77.53 & $\mathrm{bAB} \alpha$ & 92.81 & $\mathrm{aA} \alpha$ \\
\hline \multirow{2}{*}{$\mathrm{SS}^{* *}$} & \multicolumn{12}{|c|}{ Quartzo } \\
\hline & Lot A & & Lot B & & Lot $\mathrm{C}$ & & Lot D & & Lot E & & Lot F & \\
\hline $\mathrm{I}(\mathrm{OS})^{* * *}$ & 79.30 & $\mathrm{bABC} \alpha$ & 78.03 & $\mathrm{abBC} \alpha$ & 90.85 & $\mathrm{aAB} \alpha$ & 94.86 & $\mathrm{aA} \alpha$ & 90.83 & $\mathrm{aAB} \alpha$ & 65.24 & $\mathrm{bC} \alpha$ \\
\hline II (>3.0 mm) & 80.53 & $\mathrm{bA} \alpha$ & 85.6 & $\mathrm{abA} \alpha$ & 78.70 & $\mathrm{abA} \alpha$ & 76.1 & $\mathrm{bA} \alpha$ & 87.23 & $\mathrm{abA} \alpha$ & 84.93 & $\mathrm{aA} \alpha$ \\
\hline III (2.5 to $2.99 \mathrm{~mm})$ & 53.22 & $\mathrm{cB} \beta$ & 78.68 & $a b A \alpha \beta$ & 85.16 & $\mathrm{abA} \alpha$ & 83.2 & $\mathrm{abA} \alpha$ & 83.50 & $\mathrm{abA} \alpha \beta$ & 81.86 & $\mathrm{aA} \alpha$ \\
\hline IV (2.0 to $2.49 \mathrm{~mm})$ & 90.90 & $\mathrm{abA} \alpha$ & 89.86 & $\mathrm{aA} \alpha$ & 83.70 & $\mathrm{abA} \alpha$ & 82.0 & $\mathrm{abA} \alpha$ & 87.39 & $\mathrm{abA} \alpha$ & 85.26 & $\mathrm{aA} \alpha$ \\
\hline $\mathrm{V}(<2.0 \mathrm{~mm})$ & 96.9 & $\mathrm{aA} \alpha$ & 70.72 & $\mathrm{bB} \alpha$ & 73.74 & $\mathrm{bB} \alpha$ & 74.4 & $\mathrm{bB} \alpha$ & 74.10 & $\mathrm{bB} \alpha$ & 85.66 & $\mathrm{aAB} \alpha \beta$ \\
\hline \multirow{2}{*}{$\mathrm{SS}^{* *}$} & \multicolumn{12}{|c|}{ TBIO Sinuelo } \\
\hline & Lot A & & Lot B & & Lot $\mathrm{C}$ & & Lot D & & Lot E & & Lot $F$ & \\
\hline $\mathrm{I}(\mathrm{OS})^{* * *}$ & 70.74 & $\mathrm{abBC} \alpha$ & 66.10 & $\mathrm{bC} \alpha$ & 82.36 & $\mathrm{abAB} \alpha$ & 67.77 & $\mathrm{bBC} \beta$ & 89.71 & $\mathrm{aA} \alpha$ & 64.04 & $\mathrm{bC} \alpha$ \\
\hline II $(>3.0 \mathrm{~mm})$ & 76.23 & $\mathrm{abA} \alpha$ & 86.16 & $\mathrm{aA} \alpha$ & 84.63 & $\mathrm{aA} \alpha$ & 81.98 & $\mathrm{abA} \alpha$ & 78.61 & $\mathrm{abA} \alpha$ & 87.60 & $\mathrm{aA} \alpha$ \\
\hline III (2.5 to $2.99 \mathrm{~mm})$ & 85.40 & $\mathrm{aA} \alpha$ & 68.60 & $\mathrm{bB} \beta$ & 81.73 & $\mathrm{abAB} \alpha$ & 83.36 & $\mathrm{abAB} \alpha$ & 74.33 & $\mathrm{abAB} \beta$ & 79.16 & $\mathrm{abAB} \alpha$ \\
\hline IV $(2.0$ to $2.49 \mathrm{~mm})$ & 68.88 & $\mathrm{bB} \beta$ & 67.16 & $\mathrm{bB} \beta$ & 68.80 & $\mathrm{bB} \alpha$ & 88.30 & $\mathrm{aA} \alpha$ & 70.21 & $\mathrm{bB} \beta$ & 79.93 & $\mathrm{abAB} \alpha$ \\
\hline $\mathrm{V}(<2.0 \mathrm{~mm})$ & 78.08 & $\mathrm{abAB} \beta$ & 67.85 & $\mathrm{bB} \alpha$ & 86.46 & $\mathrm{aA} \alpha$ & 79.0 & $\mathrm{abAB} \alpha$ & 64.48 & $\mathrm{bB} \alpha$ & 74.46 & $\mathrm{abAB} \beta$ \\
\hline $\mathrm{CV}(\%)$ & 10.56 & & & & & & & & & & & \\
\hline
\end{tabular}

Note. *Means followed by the same lowercase letter in the column for sieve sizes, the same capitalized letter in the row for seed size between lots, and the same Greek letter between cultivars did not statistically differ by Tukey at $5 \%$ of probability of error. $* *$ SS: Size of sieve and their respective seeds retained. ${ }^{* * *}$ OS: Original sample of the lot without size fractionation.

For the cultivar Quartzo, plants from lot E defined that the main tiller height did not differ between seed sizes, however, plants originated from seeds retained in the sieve III $(2.5$ to $2.99 \mathrm{~mm})$ from lot A, V $(<2.00 \mathrm{~mm})$ sieve 
$\mathrm{V}$ of lots $\mathrm{B}, \mathrm{C}$ and $\mathrm{D}$, and original sample (OS) of lot $\mathrm{F}$ obtained lower magnitude for height of the main tiller (MTH). Among lots, the non-standardized original sample (OS) negatively affected $50 \%$ of the lots, as well as the sieve III $(2.5$ to $2.99 \mathrm{~mm})$ and $\mathrm{V}(<2.0 \mathrm{~mm})$ in $16 \%$ of the lots.

The cultivar TBIO Sinuelo expressed for main tiller height (MTH) that plants from seeds of the sieve IV (2.0 to $2.49 \mathrm{~mm}$ ) of lot A, original sample (OS), seeds retained in the sieve III (2.5 to $2.99 \mathrm{~mm})$, IV (2.0 to $2.49 \mathrm{~mm}$ ) and $\mathrm{V}(<2.0 \mathrm{~mm})$ of lot $\mathrm{B}$, as well as plants from the sieve IV $(2.0$ to $2.49 \mathrm{~mm})$ from lot $\mathrm{C}$, non-standard original sample from lots D and F, and seeds retained on sieves IV $(2.0$ to $2.49 \mathrm{~mm})$ and $\mathrm{V}(<2.0 \mathrm{~mm})$ of lot $\mathrm{E}$ presented lower height of the main tiller. Among lots, it is verified that seeds from the sieve II $(>3.00 \mathrm{~mm})$ did not differ, however, the non-standard original sample (OS) and plants from the sieve V $(<2.0 \mathrm{~mm})$ affected $33 \%$ of the lots studied, as well as the seeds of sieve III in $16 \%$, and sieve IV (2.0 to $2.49 \mathrm{~mm})$ negatively influenced $66 \%$ of the lots. It was observed that larger seeds result in higher height of the main tiller, possibly because they present greater reserve of assimilates (Sainio et al., 2011), originating plants with lower panicle mass and grain mass per panicle (Harwig et al., 2006).

The spike insertion height of the secondary tiller (SIHST) for cultivar Ametista (Table 5) showed that the standardization of seeds had no influence on lots A, C, D and F, but in lot B, the original sample (OS) without standardization, and plants originating from seeds retained in the sieve $\mathrm{V}(<2.0 \mathrm{~mm})$ of lot $\mathrm{E}$ presented lower magnitude of this trait. Smaller seeds of wheat and barley tend to reduce germination due to availability of reserves, resulting in smaller seedlings and plants (Sainio et al., 2011; Chastain et al., 1994).

Regarding the cultivar Quartzo, the spike insertion height of the secondary tiller (SIHST) of lot E defined absence of differences for plants originating from standardized seeds. In lot A, the original sample (OS) without standardization, as well as plants from seeds retained in the sieve II $(>3.0 \mathrm{~mm})$ and III (2.5 to $2.99 \mathrm{~mm})$ presented lower insertion height $(2.5$ to $2.99 \mathrm{~mm})$ for lot B, sieve II (>3.0 mm) and III (2.5 to $2.99 \mathrm{~mm})$ of lot C, as well as sieve II $(>3.0 \mathrm{~mm})$, IV $(2.0$ to $2.49 \mathrm{~mm})$ and V $(<2.0 \mathrm{~mm})$ of lot D, original sample (OS) of lot F. Among lots, it can be observed that seeds from sieve III $(2.5$ to $2.99 \mathrm{~mm})$ do not differ. However, from the original non-standardized sample (OS), sieve III $(2.5$ to $2.99 \mathrm{~mm})$ and IV (2.0 to $2.49 \mathrm{~m})$ negatively affected the insertion height of the secondary spike in $16 \%$ of the lots studied, as well as the seeds retained in the sieve V ( $<$ $2.0 \mathrm{~mm}$ ) in $66 \%$ of the lots. It is evident the importance of the lot on plant performance at field conditions, where the origin of the lots contributes to seed viability (Sainio et al., 2011). Therefore, the utilization of sieves for seed standardization allows to remove undesirable wheat seeds of a lot, providing field uniformity and competitive ability.

The cultivar TBIO Sinuelo evidenced for spike insertion height of the secondary tiller (SIHST), that lots A, B, D were not influenced by seed standardization. However, in lot C, plants from sieve IV (2.0 to $2.49 \mathrm{~mm}$ ) presented lower magnitude than the other sieves, as well as plants from sieves III (2.5 to $2.99 \mathrm{~mm})$, IV (2.0 to $2.49 \mathrm{~mm})$ and $\mathrm{V}(<2.0 \mathrm{~mm})$ of lot $\mathrm{E}$, original sample $(\mathrm{OS})$ and sieve $\mathrm{V}(<2.0 \mathrm{~mm})$ of lot $\mathrm{F}$. Among lots, seeds retained in sieve III $(2.5$ to $2.99 \mathrm{~mm})$ provided plants with insertion height of the secondary tiller similar for all lots, however, the original sample of $16 \%$ of the lots had lower height, as well as the seeds retained in sieves II $(>3.0$ $\mathrm{mm}$ ) of $33 \%$, sieve IV (2.0 to $2.49 \mathrm{~mm})$ of $50 \%$, sieve $\mathrm{V}(<2.0 \mathrm{~mm})$ of $83 \%$ of the lots.

Considering the height of secondary tiller (HST) for cultivar Ametista, lots A, C, D, and F (Table 5) did not differ for seeds standardization. However, plants originating from the original sample (OS) of lot B, and seeds retained in the sieve $\mathrm{V}(<2.0 \mathrm{~mm})$ of lot E presented lower magnitude. Among the lots, plants from seeds retained on sieve IV $(2.0$ to $2.49 \mathrm{~mm})$ and $\mathrm{V}(<2.0 \mathrm{~mm})$ were similar, but the non-standardized original sample (OS) negatively affected $33 \%$ of the lots, possibly due to the difference between seeds in each lot, and the plants originating from sieves II (>3.0 mm) and III ( 2.5 to $2.99 \mathrm{~mm})$ in $16 \%$ of the lots. In this way, fractioning lots of wheat seeds may positively influence spike insertion height.

For cultivar Quartzo, the standardization of lots $\mathrm{C}$ and $\mathrm{E}$ did not influence the height of secondary tillers, however, the non-standard original sample (OS), and plants from the sieve II (>3.0 mm) and III (2.5 to $2.99 \mathrm{~mm})$ of lot A presented lower magnitude, as well as sieve III ( 2.5 to $2.99 \mathrm{~mm}$ ) of lot B, sieve II (> $3.0 \mathrm{~mm})$, IV (2.0 to $2.49 \mathrm{~mm})$ and $\mathrm{V}(<2.0 \mathrm{~mm})$ of lot $\mathrm{D}$, and original sample (OS) not standardized of lot $\mathrm{F}$. Among lots, plants from seeds retained in sieve II $(>3.0 \mathrm{~mm})$ did not differ. For seeds from original sample (OS), $33 \%$ of the lots studied were affected, as well as seeds retained on sieve III ( 2.5 to $2.99 \mathrm{~mm}$ ) and IV (2.0 to $2.49 \mathrm{~mm})$ in $16 \%$ of the lots, and sieve $\mathrm{V}(<2.0 \mathrm{~mm})$ in $50 \%$ of the lots. Researches have determined that small seeds tend to increase the variability of plant height and seedling (Sainio et al., 2011). 
Table 5. Means for interaction among cultivars $\times$ seed sizes $\times$ lots for the traits spike insertion height of the secondary tiller (SIHST) and height of secondary tiller (HST)

\begin{tabular}{|c|c|c|c|c|c|c|c|c|c|c|c|c|}
\hline \multicolumn{13}{|c|}{ Spike insertion height of the secondary tiller $(\mathrm{cm})$} \\
\hline \multirow{2}{*}{$\mathrm{SS}^{* *}$} & \multicolumn{12}{|c|}{ Ametista } \\
\hline & Lot $\mathrm{A}$ & & Lot B & & Lot $\mathrm{C}$ & & Lot D & & Lot E & & Lot $\mathrm{F}$ & \\
\hline $\mathrm{I}(\mathrm{OS}) * * *$ & 38.70 & $\mathrm{aAB} \alpha$ & 33.16 & $\mathrm{bB} \beta$ & 52.73 & $\mathrm{aAB} \alpha$ & 59.03 & $\mathrm{aA} \alpha \beta$ & 56.33 & $\mathrm{abA} \alpha$ & 44.53 & $\mathrm{aAB} \alpha$ \\
\hline $\mathrm{II}(>3.0 \mathrm{~mm})$ & 30.90 & $\mathrm{aB} \alpha$ & 51.99 & $\mathrm{abA} \alpha$ & 59.3 & $\mathrm{aA} \alpha$ & 58.37 & $\mathrm{aA} \alpha$ & 69.03 & $\mathrm{aA} \alpha$ & 58.86 & $\mathrm{aA} \alpha$ \\
\hline III (2.5 to $2.99 \mathrm{~mm})$ & 46.97 & $\mathrm{aA} \alpha$ & 61.00 & $\mathrm{aA} \alpha$ & 48.13 & $\mathrm{aA} \alpha$ & 56.43 & $\mathrm{aA} \alpha$ & 67.36 & $\mathrm{abA} \alpha$ & 56.26 & $\mathrm{aA} \alpha$ \\
\hline IV (2.0 to $2.49 \mathrm{~mm})$ & 47.43 & $\mathrm{aA} \alpha$ & 63.33 & $\mathrm{aA} \alpha$ & 52.85 & $\mathrm{aA} \alpha$ & 48.99 & $\mathrm{aA} \alpha \beta$ & 51.56 & $\mathrm{abA} \alpha \beta$ & 51.3 & $\mathrm{aA} \alpha$ \\
\hline $\mathrm{V}(<2.0 \mathrm{~mm})$ & 51.10 & $\mathrm{aA} \alpha \beta$ & 55.06 & $\mathrm{aA} \alpha$ & 63.16 & $\mathrm{aA} \alpha$ & 58.8 & $\mathrm{aA} \alpha$ & 48.1 & $\mathrm{bA} \alpha$ & 64.06 & $\mathrm{aA} \alpha$ \\
\hline \multirow{2}{*}{$\mathrm{SS}^{* *}$} & \multicolumn{12}{|c|}{ Quartzo } \\
\hline & Lot A & & Lot B & & Lot $\mathrm{C}$ & & Lot D & & Lot E & & Lot $\mathrm{F}$ & \\
\hline $\mathrm{I}(\mathrm{OS}) * * *$ & 42.53 & $\mathrm{bBC} \alpha$ & 58.83 & $\mathrm{aAB} \alpha$ & 65.53 & $\mathrm{aA} \alpha$ & 66.06 & $\mathrm{aA} \alpha$ & 51.96 & $\mathrm{aAB} \alpha$ & 29.79 & $\mathrm{bC} \alpha$ \\
\hline II $(>3.0 \mathrm{~mm})$ & 41.96 & $\mathrm{bA} \alpha$ & 56.83 & $\mathrm{abA} \alpha$ & 43.89 & $\mathrm{bA} \alpha$ & 41.92 & $\mathrm{bA} \alpha$ & 55.52 & $\mathrm{aA} \alpha$ & 49.86 & $\mathrm{abA} \alpha$ \\
\hline III (2.5 to $2.99 \mathrm{~mm})$ & 33.20 & $\mathrm{bB} \alpha$ & 37.93 & $\mathrm{bAB} \beta$ & 41.65 & $\mathrm{bAB} \alpha$ & 49.16 & $\mathrm{abAB} \alpha$ & 57.13 & $\mathrm{aA} \alpha \beta$ & 42.90 & $\mathrm{abAB} \alpha$ \\
\hline IV (2.0 to $2.49 \mathrm{~mm})$ & 52.16 & $\mathrm{abAB} \alpha$ & 53.76 & $\mathrm{abA} \alpha \beta$ & 60.68 & $\mathrm{abA} \alpha$ & 32.70 & $\mathrm{bB} \beta$ & 58.34 & $\mathrm{aA} \alpha$ & 48.00 & $\mathrm{abAB} \alpha$ \\
\hline $\mathrm{V}(<2.0 \mathrm{~mm})$ & 68.65 & $\mathrm{aA} \alpha$ & 43.77 & $\mathrm{abB} \alpha$ & 45.30 & $\mathrm{abB} \beta$ & 37.20 & $\mathrm{bB} \beta$ & 40.26 & $\mathrm{aB} \alpha \beta$ & 54.80 & $\mathrm{aAB} \alpha$ \\
\hline \multirow{2}{*}{$\mathrm{SS}^{* *}$} & \multicolumn{12}{|c|}{ TBIO Sinuelo } \\
\hline & Lot A & & Lot B & & Lot $\mathrm{C}$ & & Lot D & & Lot E & & Lot $\mathrm{F}$ & Lot A \\
\hline $\mathrm{I}(\mathrm{OS}) * * *$ & 25.79 & $\mathrm{aC} \alpha$ & 33.55 & $\mathrm{aBC} \beta$ & 49.43 & $\mathrm{aAB} \alpha$ & 41.03 & $\mathrm{aBC} \beta$ & 65.3 & $\mathrm{aA} \alpha$ & 30.53 & $\mathrm{bBC} \alpha$ \\
\hline $\mathrm{II}(>3.0 \mathrm{~mm})$ & 41.33 & $\mathrm{aB} \alpha$ & 42.40 & $\mathrm{aB} \alpha$ & 55.69 & $\mathrm{aAB} \alpha$ & 45.93 & $\mathrm{aAB} \alpha$ & 63.89 & $\mathrm{aA} \alpha$ & 45.53 & $\mathrm{abAB} \alpha$ \\
\hline III ( 2.5 to $2.99 \mathrm{~mm})$ & 45.73 & $\mathrm{aA} \alpha$ & 38.73 & $\mathrm{aA} \beta$ & 56.66 & $\mathrm{aA} \alpha$ & 48.90 & $\mathrm{aA} \alpha$ & 39.70 & $\mathrm{bA} \beta$ & 55.63 & $\mathrm{aA} \alpha$ \\
\hline IV (2.0 to $2.49 \mathrm{~mm})$ & 45.89 & $\mathrm{aAB} \alpha$ & 35.63 & $\mathrm{aB} \beta$ & 28.00 & $\mathrm{bB} \beta$ & 59.73 & $\mathrm{aA} \alpha$ & 31.27 & $\mathrm{bB} \beta$ & 46.23 & $\mathrm{abAB} \alpha$ \\
\hline $\mathrm{V}(<2.0 \mathrm{~mm})$ & 37.79 & $\mathrm{aB} \beta$ & 37.90 & $\mathrm{aB} \alpha$ & 62.86 & $\mathrm{aA} \alpha$ & 39.84 & $\mathrm{aB} \alpha \beta$ & 25.16 & $\mathrm{bB} \beta$ & 33.26 & $\mathrm{bB} \beta$ \\
\hline $\mathrm{CV}(\%)$ & 83.17 & & & & & & & & & & & \\
\hline \multicolumn{13}{|c|}{ Height of secondary tiller $(\mathrm{cm})$} \\
\hline \multirow{2}{*}{$\mathrm{SS}^{* *}$} & \multicolumn{12}{|c|}{ Ametista } \\
\hline & Lot A & & Lot B & & Lot $\mathrm{C}$ & & Lot D & & Lot $\mathrm{E}$ & & Lot $\mathrm{F}$ & \\
\hline $\mathrm{I}(\mathrm{OS}) * * *$ & 41.53 & $\mathrm{aB} \alpha$ & 35.9 & $\mathrm{bB} \beta$ & 56.73 & $\mathrm{aAB} \alpha$ & 64.03 & $\mathrm{aA} \alpha \beta$ & 64.33 & $\mathrm{abA} \alpha$ & 48.5 & $\mathrm{aAB} \alpha$ \\
\hline $\mathrm{II}(>3.0 \mathrm{~mm})$ & 33.10 & $\mathrm{aB} \alpha$ & 55.86 & $\mathrm{abA} \alpha$ & 64.23 & $\mathrm{aA} \alpha$ & 63.62 & $\mathrm{aA} \alpha$ & 75.56 & $\mathrm{aA} \alpha$ & 63.5 & $\mathrm{aA} \alpha$ \\
\hline III (2.5 to $2.99 \mathrm{~mm})$ & 50.69 & $\mathrm{aB} \alpha$ & 65.73 & $\mathrm{aAB} \alpha$ & 52.06 & $\mathrm{aAB} \alpha$ & 61.26 & $\mathrm{aAB} \alpha$ & 73.56 & $\mathrm{abA} \alpha$ & 60.70 & $\mathrm{aAB} \alpha$ \\
\hline IV (2.0 to $2.49 \mathrm{~mm})$ & 51.50 & $\mathrm{aA} \alpha$ & 68.13 & $\mathrm{aA} \alpha$ & 56.21 & $\mathrm{aA} \alpha$ & 53.09 & $\mathrm{aA} \alpha \beta$ & 56.13 & $\mathrm{abA} \alpha \beta$ & 55.6 & $\mathrm{aA} \alpha$ \\
\hline $\mathrm{V}(<2.0 \mathrm{~mm})$ & 55.12 & $\mathrm{aA} \alpha \beta$ & 60.15 & $\mathrm{aA} \alpha$ & 68.71 & $\mathrm{aA} \alpha$ & 63.76 & $\mathrm{aA} \alpha$ & 52.03 & $\mathrm{bA} \alpha$ & 69.56 & $\mathrm{aA} \alpha$ \\
\hline \multirow{2}{*}{$\mathrm{SS}^{* *}$} & \multicolumn{12}{|c|}{ Quartzo } \\
\hline & Lot A & & Lot B & & Lot $\mathrm{C}$ & & Lot D & & Lot $\mathrm{E}$ & & Lot $\mathrm{F}$ & \\
\hline $\mathrm{I}(\mathrm{OS}) * * *$ & 46.06 & $\mathrm{bB} \alpha$ & 63.62 & $\mathrm{aA} \alpha$ & 67.93 & $\mathrm{aA} \alpha$ & 71.66 & $\mathrm{aA} \alpha$ & 56.50 & $\mathrm{aA} \alpha$ & 32.43 & $\mathrm{bB} \alpha$ \\
\hline $\mathrm{II}(>3.0 \mathrm{~mm})$ & 45.53 & $\mathrm{bA} \alpha$ & 61.93 & $\mathrm{abA} \alpha$ & 47.05 & $\mathrm{aA} \alpha$ & 45.28 & $\mathrm{bA} \alpha$ & 60.41 & $\mathrm{aA} \alpha$ & 54.13 & $\mathrm{abA} \alpha$ \\
\hline III $(2.5$ to $2.99 \mathrm{~mm})$ & 35.87 & $\mathrm{bB} \alpha$ & 40.97 & $\mathrm{bAB} \beta$ & 48.18 & $\mathrm{aAB} \alpha$ & 53.40 & $\mathrm{abAB} \alpha$ & 61.93 & $\mathrm{aA} \alpha \beta$ & 46.36 & $\mathrm{abAB} \alpha$ \\
\hline IV $(2.0$ to $2.49 \mathrm{~mm})$ & 46.30 & $\mathrm{abAB} \alpha$ & 55.66 & $\mathrm{abAB} \alpha \beta$ & 62.57 & $\mathrm{aA} \alpha$ & 35.10 & $\mathrm{bB} \beta$ & 63.40 & $\mathrm{aA} \alpha$ & 52.16 & $\mathrm{abAB} \alpha$ \\
\hline $\mathrm{V}(<2.0 \mathrm{~mm})$ & 69.67 & $\mathrm{aA} \alpha$ & 47.2 & $\mathrm{abB} \alpha$ & 49.56 & $\mathrm{aAB} \alpha$ & 40.53 & $\mathrm{bB} \beta$ & 43.56 & $\mathrm{aB} \alpha \beta$ & 59.76 & $\mathrm{aAB} \alpha$ \\
\hline \multirow{2}{*}{ SS** } & \multicolumn{12}{|c|}{ TBIO Sinuelo } \\
\hline & Lot A & & Lot B & & Lot $\mathrm{C}$ & & Lot D & & Lot E & & Lot $F$ & \\
\hline $\mathrm{I}(\mathrm{OS})^{* * *}$ & 27.86 & $\mathrm{aB} \alpha$ & 36.31 & $\mathrm{aB} \beta$ & 53.53 & $\mathrm{aA} \alpha$ & 44.46 & $\mathrm{aB} \beta$ & 69.75 & $\mathrm{aA} \alpha$ & 33.09 & $\mathrm{bB} \alpha$ \\
\hline $\mathrm{II}(>3.0 \mathrm{~mm})$ & 44.66 & $\mathrm{aB} \alpha$ & 43.13 & $\mathrm{aB} \alpha$ & 60.45 & $\mathrm{aAB} \alpha$ & 49.25 & $\mathrm{aAB} \alpha$ & 69.12 & $\mathrm{aA} \alpha$ & 55.93 & $\mathrm{abAB} \alpha$ \\
\hline III $(2.5$ to $2.99 \mathrm{~mm})$ & 49.80 & $\mathrm{aA} \alpha$ & 41.76 & $\mathrm{aA} \beta$ & 61.30 & $\mathrm{aA} \alpha$ & 53.66 & $\mathrm{aA} \alpha$ & 42.90 & $\mathrm{bA} \beta$ & 60.13 & $\mathrm{aA} \alpha$ \\
\hline IV (2.0 to $2.49 \mathrm{~mm})$ & 49.90 & $\mathrm{aAB} \alpha$ & 38.69 & $\mathrm{aB} \beta$ & 29.96 & $\mathrm{bB} \beta$ & 65.16 & $\mathrm{aA} \alpha$ & 34.22 & $\mathrm{bB} \beta$ & 49.80 & $\mathrm{abAB} \alpha$ \\
\hline $\mathrm{V}(<2.0 \mathrm{~mm})$ & 43.12 & $\mathrm{aB} \beta$ & 41.07 & $\mathrm{aB} \alpha$ & 68.34 & $\mathrm{aA} \alpha$ & 43.25 & $\mathrm{aB} \alpha \beta$ & 27.33 & $\mathrm{bB} \beta$ & 35.73 & $\mathrm{bB} \beta$ \\
\hline $\mathrm{CV}(\%)$ & 83.28 & & & & & & & & & & & \\
\hline
\end{tabular}

Note. *Means followed by the same lowercase letter in the column for sieve sizes, the same capitalized letter in the row for seed size between lots, and the same Greek letter between cultivars did not statistically differ by Tukey at $5 \%$ of probability of error. $* *$ SS: Size of sieve and their respective seeds retained. ${ }^{* *}$ OS: Original sample of the lot without size fractionation.

The cultivar TBIO Sinuelo, for lots A, B and D did not differ among seed sizes, however, seeds from the sieve IV (2.0 to $2.49 \mathrm{~mm}$ ) of lot $\mathrm{C}$ resulted in lower magnitude for plant height of secondary tillers, as well as those retained in sieves III $(2.5$ to $2.99 \mathrm{~mm}), \mathrm{IV}(2.0$ to $2.49 \mathrm{~mm}), \mathrm{V}(<2.0 \mathrm{~mm})$ of lot E, and original sample (OS), 
seeds retained in sieve $\mathrm{V}(<2.0 \mathrm{~mm})$ of lot $\mathrm{F}$. Among the lots evaluated, plants from sieve III (2.5 to $2.99 \mathrm{~mm})$ did not differ, however, the original sample (OS) and seeds of sieve IV (2.0 to $2.49 \mathrm{~mm}$ ) negatively influenced $50 \%$ of the lots studied, as well as seeds of the sieve II $(>3.0 \mathrm{~mm})$ in $33 \%$ of the lots, and the sieve V in $83 \%$ of the lots, were the plants had smaller height of secondary tillers.

In general, there was variation among lots and cultivars tested in response to seeds standardization. Also, the standardization allowed to identify the variability between lots and sieve sizes, with the tendency that plants originated from original samples (OS) non-standardized and smaller seeds present inferior performance at field, as well as, bigger seeds may potentiate the magnitude of fertile tillers and plant height.

\section{Conclusions}

The size of the seeds, lot and cultivar cause variation in the number of tillers per plant, plant height and spike insertion.

Seeds of smaller size result in lower plants.

The use of sieves to standardize wheat seeds allows separating lots with specific characteristics of field performance.

\section{References}

Barbosa, C. Z. R., Smiderle, O. J., Alves, J. M. A., Vilarinho, A. A., \& Sediyama, T. (2010). Qualidade de sementes de soja BRS Tracajá, colhidas em Roraima em função do tamanho no armazenamento. Revista Ciência Agronômica, 41(1), 73-80.

Bredemeier, C., Mundstock, C. M., \& Buttenbender, D. (2001). Efeito do tamanho das sementes de trigo no desenvolvimento inicial das plantas e no rendimento de grãos. Pesquisa Agropecuária Brasileira, 36(8), 1061-1068. https://doi.org/10.1590/S0100-204X2001000800008

Brzezinski, C. R., Zucareli, C., Henning, F. A., Abati, J., Prando, A. M., \& Henning, A. A. (2014). Nitrogênio e inoculação com Azospirillum na qualidade fisiológica e sanitária de sementes de trigo. Revista de Ciências Agrárias Amazonian Joutnal og Agricultural and Environmental Sciences, 57(3), 257-265. https://doi. org/10.4322/rca.ao1391

Carvalho, I. R., Nardino, M., Demari, G. H., Pelegrin, A. J., Ferrari, M., Szareski, V. J., ... Souza, V. Q. (2016). Sowing date and multivariate analisys of yield and physiological components in elite wheat genotypes. International Journal of Current Research, 08(11), 40828-40833.

Carvalho, I. R., Follmann, D. N., Demari, G. H., Olivoto, T., Pelegrin, A. J., Szareski ,V. J., ... Souza V.Q. (2017). Path analysis of grain yield associated characters in Brazilians wheat genotypes (Triticum aestivumL.). Australian Journal of Crop Science, 11(11), 1406-1410. https://doi.org/10.21475/ajcs.17.11.11. pne 484

Chastain, T. G., Ward, K. J., \& Wysocki, D. J. (1994). Stand Establishment Response of Soft White Winter Wheat to Seedbed Residue and Seed Size. CropSciencie Society of America, 35(1), 213-218.

CONAB (Companhia Nacional de Abastecinto). (2018). Acompanhamento da safra brasileira de grãos. 5, safra 2017/2018, n.5, Quinto levantamento.

CQFS-RS/SC (Comissão de Química e Fertilidade do Solo). (2004). Manual de adubação e calagem para os estados do Rio Grande do Sul e Santa Catarina (10th ed., p. 400). Porto Alegre: Sociedade Brasileira de Ciência do Solo/Núcleo Regional Sul.

FAO (Food and Agriculture Organization of the United Nations). (2017). World Food Situation: Cereal Supply and Demand Brief.

Ferreira, E. A., Concenço, G., Silva, A. A., Reis, M. R., Vargas, L., Viana, R. G., ... Galon, L. (2008). Potencial competitivo de biótipos de azevém (Lolium multiflorum). Planta Daninha, 26(2), 261-269. https://doi.org/ $10.1590 / \mathrm{S} 0100-83582008000200002$

Hartwig, I., Carvalho, F. I. F., Oliveira, A. C., Silva, J. A. G., Lorencetti, B. G., Vieira, E. A., ... Scmidt, D. A. M. (2006). Correlações fenotípicas entre caracteres agronômicos de interesse em cruzamentos dialélicos de aveia branca. Revista Brasileira de Agrociência, 12(3), 273-278.

Martins, C. C., Trevisoli, S. H. U., Môro, G. V., \& Vieira, R. D. (2016). Metodologia para seleção de linhagens de soja visando germinação, vigor e emergência em campo. Revista Ciência Agronômica, 47(3), 455-461. https://doi.org/10.5935/1806-6690.20160055 
Ormond, A. T. S., Nunes, J. A. S., Caneppele, C., Silva, S. L. S., \& Pereira, M. T. J. (2013). Analise das caracteristicas físicas de sementes de trigo. Enciclopédia Biosfera, Centro Científico Conhecer-Goiânia, $9(17), 108-114$

Ohlson, O. D. C., Krzyzanowski, F. C., Caieiro, J. T., \& Panobianco, M. (2010). Teste de envelhecimento acelerado em sementes de trigo. Revista Brasileira de Sementes, 32(4), 118-124. https://doi.org/10.1590/ S0101-31222010000400013

Pádua, G. P., Zito, R. K., Arantes, N. E., \& Neto, J. D. B. F. (2010). Influência do tamanho da semente na qualidade fisiológica e na produtividade da cultura da soja. Revista Brasileira de Sementes, 32(3), 009-016. https://doi.org/10.1590/S0101-31222010000300001

Ramalho, M. A. P., Abreu, A. F. B., Santos, J. B., \& Nunes, J. A. R. (2012). Aplicações da genética quantitativa no melhoramento de plantas autógamas (p. 350). Lavras, UFLA.

Sainio, P. P., Rajala, A., \& Jauhiainen, L. (2011). Hidden viability risks in the use of farm-saved small-grain seed. Journal of Agricultural Science, 149, 713-724. https://doi.org/10.1017/S0021859611000335

Silva, J. A. G., Carvlho, F. I. F., Oliveira, A. C., Vieira, E. A., Benin, O. P., Carvalho, M. F., ... Ribeiro, G. (2006) Correlação de acamamento com rendimento de grãos e outros caracteres de interesse agronômico em plantas de trigo. Ciência Rural, Santa Maria, 36(3), 756-764. https://doi.org/10.1590/S010384782006000300006

Sotério, P. W., Pedrollo, M. C., \& Andriotti, J. L. (2005). Mapa de isoietas do Rio Grande do Sul. Porto Alegre.

Streck, E. V., Kämpf, N., Dalmolin, R. S. D., Klamt, E., Nascimento, P. C., Schneider, P., ... Pinto, L. F. S. (2008). Solos do Rio Grande do Sul (2nd ed., p. 222). Porto Alegre: EMATER/RS.

Valério, I. P., Carvalho, F. I. F., Oliveira, A. C., Machado, A. A., Scheeren, P. L., Souza, V. Q., \& Hartwig, I. (2008). Desenvolvimento de afilhos e componentes do rendimento em cultivares de trigo sob diferentes densidades de semeadura. Pesquisa Agropecuária Brasileira, 43(3), 319-326. https://doi.org/10.1590/ S0100-204X2008000300005

Vazquez, G. H., Arf, O., Sargi, B. A., \& Pessoa, A. C. O. (2012). Influência do tamanho e da forma da semente de milho sobre o desenvolvimento da planta e a produtividade de grãos. Bioscience Journal, 28(1), 16-24.

\section{Copyrights}

Copyright for this article is retained by the author(s), with first publication rights granted to the journal.

This is an open-access article distributed under the terms and conditions of the Creative Commons Attribution license (http://creativecommons.org/licenses/by/4.0/). 